\title{
Factors Related to Body Mass Index in Women with Rheumatoid Arthritis - TOMORROW study
}

\author{
Yoshinari Matsumoto ${ }^{1}$, Yuko Sugioka ${ }^{2}$, Masahiro Tada ${ }^{3}$, Tadashi Okano ${ }^{3}$, Kenji Mamoto ${ }^{3}$, \\ Kentaro Inui ${ }^{4}$, Daiki Habu ${ }^{1}$ and Tatsuya Koike ${ }^{2,5,{ }^{*}}$ \\ ${ }^{1}$ Department of Medical Nutrition, Osaka City University Graduate School of Human Life Science, 3-3-138 \\ Sugimoto-cho, Sumiyoshi-ku, Osaka 558-8585, Japan \\ ${ }^{2}$ Center for Senile Degenerative Disorders (CSDD), Osaka City University Medical School, 1-4-3 Asahimachi, \\ Abeno-ku, Osaka 545-8585, Japan \\ ${ }^{3}$ Department of Orthopaedic Surgery, Osaka City University Medical School, 1-4-3 Asahimachi, Abeno-ku, \\ Osaka 545-8585, Japan \\ ${ }^{4}$ Department of Rheumatosurgery, Osaka City University Medical School, 1-4-3 Asahimachi, Abeno-ku, \\ Osaka 545-8585, Japan \\ ${ }^{5}$ Search Institute for Bone and Arthritis Disease (SINBAD), Shirahama Foundation for Health and Welfare, \\ 1447 Shirahama-cho, Nishimuro-gun, Wakayama 649-2211, Japan
}

\begin{abstract}
Objectives: This study aimed to clarify the relationship between body mass index (BMI) and patient characteristics, lifestyle factors, and cardiovascular disease (CVD)-related clinical data in women with rheumatoid arthritis (RA).

Methods: A total of 171 female outpatients with RA and 170 age-matched females without RA (controls) from the TOMORROW study (UMIN: 000003876) were included in this cross-sectional study. We divided subjects into 3 groups based on BMI: underweight (BMI $\left.<18.5 \mathrm{~kg} / \mathrm{m}^{2}\right)$, normal weight $\left(\mathrm{BMI} \geq 18.5 \mathrm{~kg} / \mathrm{m}^{2}\right.$ and $\left.<25 \mathrm{~kg} / \mathrm{m}^{2}\right)$, and overweight (BMI $\geq 25 \mathrm{~kg} / \mathrm{m}^{2}$ ), and compared RA disease activity, activities of daily living (ADL) assessed by modified health assessment questionnaire (mHAQ) score, energy and nutrient intake, and CVD risk-related clinical data.

Results: In patients with RA, mHAQ scores were lower in the normal weight group compared with the underweight and overweight groups $(p<0.05)$. Disease activity showed a similar trend. Energy, protein, and carbohydrate intake showed a positive correlation with $\mathrm{BMI}(p<0.05)$. Blood pressure, C-reactive protein, uric acid, triglyceride, fasting plasma glucose, immune reactive insulin, $\mathrm{HbA} 1 \mathrm{c}$, and leptin showed a positive correlation with $\mathrm{BMI}$, and adiponectin showed a negative correlation with BMI $(p<0.05)$. Control subjects showed similar trends.

Conclusions: $\mathrm{BMI}$ is related to $\mathrm{ADL}$, disease activity, energy, protein and carbohydrate intake, and CVD risk-related clinical data, and might be an indicator of total health status in female patients with RA.
\end{abstract}

Keywords: Rheumatoid arthritis, underweight, obesity, nutrition, cardiovascular disease, lifestyle.

\section{BACKGROUND}

A recent report showed that $36.9 \%$ of males and $38.0 \%$ of females worldwide are overweight or obese, defined as a body mass index (BMI) $>25 \mathrm{~kg} / \mathrm{m}^{2}$ [1]. Although the definitions of overweight and obesity differ among professional associations and published guidelines, all publications agree that obesity is related to hypertension, glucose intolerance, dyslipidemia [2], and increases in cardiovascular disease (CVD) risk [3].

Worldwide, about $1 \%$ of the population has rheumatoid arthritis (RA), defined as an autoimmune disorder that results in disruption of joints and chronic inflammation [4]. CVD risk in patients with RA is higher

*Address correspondence to this author at the Search Institute for Bone and Arthritis Disease (SINBAD), Shirahama Foundation for Health and Welfare, 1447 Shirahama-cho, Nishimuro-gun, Wakayama 649-2211, Japan; Tel: +81739-43-6200; Fax:+81-739-43-7891; E-mail: tatsuya@med.osaka-cu.ac.jp than in subjects without RA [5], and obesity affects the RA patient's risk for CVD [6]. Reports indicate that obesity in patients with RA decreases quality of life (QOL), activities of daily living (ADL) [7], and the effect of anti-rheumatic medications [8]. Therefore, prevention and improvement of obesity are thought to be important in patients with RA. On the other hand, a relationship between increased inflammation and decreases in BMI in patients with RA have been reported [9], and underweight has been shown to be related to low $\mathrm{QOL}$ and ADL [10], and increases CVD risk [11] in patients with RA. These findings suggest the importance of maintaining a normal body weight, that is, neither underweight nor overweight.

Body weight is mainly affected by lifestyle factors such as energy and nutrient intake and exercise. However, few reports have investigated the relationship between body weight and lifestyle factors on patients 
with $\mathrm{RA}$, or the relationship between $\mathrm{BMI}$ and disease activity, ADL, and CVD-related clinical data in patients with RA. We aimed to clarify the relationships between BMI and lifestyle factors, and also compared ADL, disease activity, and CVD-related clinical data in female patients with RA divided into underweight, normal, and overweight categories based on BMI.

\section{MATERIALS AND METHODS}

\section{Study Design}

In this study, we used year 2011 data from 171 female RA outpatients and 170 age-matched controls without RA who participated in the TOMORROW study (UMIN: 000003876). TOMORROW is a 10-year prospective cohort study conducted in Osaka City University Medical School starting in 2010 that includes 208 Japanese patients with RA and 205 age- and sexmatched Japanese subjects without RA [12]. All of the study's subjects are older than 20 years and control subjects were recruited by mass media. We performed a sub-analysis of 2011 data in this cross-sectional study. This study was conducted with approval from the Ethics Committee at Osaka City University Medical School, and all participants provided written, informed consent based on the Declaration of Helsinki. A diagnosis of RA was made according to the American College of Rheumatology criteria [13]. Using the year 2010 baseline registration data gained through a questionnaire, we assessed subjects' basic status regarding smoking, alcohol intake, current exercise habits, current exercise restrictions from doctors, walking time per day, and history and treatment for diabetes mellitus, dyslipidemia, and hypertension. BMI was calculated as weight divided by square of height $\left(\mathrm{kg} / \mathrm{m}^{2}\right)$, and we divided patients into three BMI categories: underweight $\left(\mathrm{BMI}<18.5 \mathrm{~kg} / \mathrm{m}^{2} ; \mathrm{RA}, \mathrm{n}=21\right.$; controls, $n=23$ ), normal weight (BMI $\geq 18.5$ and $<25$ $\mathrm{kg} / \mathrm{m}^{2}$; RA, $\mathrm{n}=112$; controls, $\mathrm{n}=119$ ), and overweight (BMI $\geq 25 \mathrm{~kg} / \mathrm{m}^{2} ; \mathrm{RA}, \mathrm{n}=38$; controls, $\mathrm{n}=28$ ) [14]. Because the number of subjects with a BMI $>30 \mathrm{~kg} / \mathrm{m}^{2}$ was limited in both the RA group $(n=7)$ and control group $(n=3)$, we included these subjects in the overweight category. We set the ideal body weight $($ IBW) as the square of height $(m) \times 22$ [15].

\section{Disease Activity and ADL Assessment}

Disease Activity Score for 28 joints based on erythrocyte sedimentation rate (DAS28-ESR) was used to assess disease activity [16], and the modified Health Assessment Questionnaire (mHAQ) was used to evaluate ADL [17]. Higher mHAQ scores indicate a lower ADL level.

\section{Energy and Nutrient Intake Assessment}

A brief-type dietary history questionnaire was used to assess energy and nutrient intake [18], and we excluded one subject in both the RA and control groups who had low energy intake (less than $600 \mathrm{kcal}$ per day) [12].

\section{Blood Chemistry and Physiological Assessment}

We assessed systolic blood pressure (SBP), diastolic blood pressure (DBP), erythrocyte sedimentation rate (ESR), C-reactive protein (CRP), uric acid (UA), total cholesterol (T-chol), triglycerides (TG), high-density lipoprotein cholesterol, (HDL-chol), low-density lipoprotein cholesterol (LDL-chol), fasting plasma glucose (FPG), immunoreactive insulin (IRI), $\mathrm{HbA1c}$, leptin, and adiponectin. Blood samples were collected after an overnight fast, and serum samples were stored at $-80^{\circ} \mathrm{C}$ before analysis in 2010 .

\section{Statistical Analysis}

Dr. SPSS II for Windows, version 11.0.1J (SPSS Japan Inc., Tokyo, Japan) was used for statistical analysis. Data are shown as number of subjects (\%) or median (interquartile range [IQR]) because data were not normal distribution. The Kruskal-Wallis test and chisquare test were used to analyze differences between the three groups, and the Jonckheere-Terpstra test was used to estimate the trend of the $p$ value. Correlation coefficient $(\mathrm{R})$ was calculated as an age adjusted value for adjusting variable collinearity; values $>0.20$ represented a correlation. A $p$ value $<0.05$ was considered statistically significant.

\section{RESULTS}

\section{Subjects' Characteristics Based on BMI Group}

Subjects' characteristics by BMI group are shown in Table 1. In the RA group, there were significant differences in age $(p=0.010)$, waist circumference $(p<$ $0.001)$, mHAQ score $(p=0.035)$, and the number of patients with a history of smoking $(p=0.008)$ among the three groups. DAS28-ESR, the number of patients with a history of diabetes mellitus, and the number of patients with a history of hypertension had a tendency to differ among the three groups. Age had a tendency to increase with BMI. There were no significant differences in exercise or medication status among the 
Table 1: Subject Characteristics by BMI Group

\begin{tabular}{|c|c|c|c|c|c|c|c|c|c|c|}
\hline & \multicolumn{5}{|c|}{$\operatorname{RA}(n=171)$} & \multicolumn{5}{|c|}{ Control $(n=170)$} \\
\hline & $\begin{array}{c}\text { UW } \\
(n=21)\end{array}$ & $\begin{array}{c}N W \\
(n=112)\end{array}$ & $\begin{array}{c}\text { OW } \\
(n=38)\end{array}$ & $\begin{array}{c}p \\
\text { value }\end{array}$ & $\begin{array}{l}p \text { for } \\
\text { trend }\end{array}$ & $\begin{array}{c}\text { UW } \\
(n=23)\end{array}$ & $\begin{array}{c}N W \\
(n=119)\end{array}$ & $\begin{array}{c}\text { OW } \\
(n=28)\end{array}$ & $\begin{array}{c}p \\
\text { value }\end{array}$ & $\begin{array}{l}p \text { for } \\
\text { trend }\end{array}$ \\
\hline Age (years) & $55(21.5)$ & $60(18.5)$ & $66(12.5)$ & 0.034 & 0.010 & $57(10.0)$ & $61(17.0)$ & $61(16.0)$ & 0.262 & 0.354 \\
\hline Height (cm) & $155.2(8.9)$ & $153.9(10.8)$ & $150.8(10.7)$ & 0.025 & 0.008 & $158.1(8.1)$ & $155.0(8.3)$ & $155.5(8.3)$ & 0.371 & 0.477 \\
\hline Weight (kg) & $43.3(5.5)$ & $50.8(8.9)$ & $63.6(9.0)$ & $<0.001$ & $<0.001$ & $43.9(6.6)$ & $52.9(6.4)$ & $63.6(11.6)$ & $<0.001$ & $<0.001$ \\
\hline $\mathrm{BMI}\left(\mathrm{kg} / \mathrm{m}^{2}\right)$ & $18.1(0.8)$ & $21.2(3.2)$ & $27.3(2.9)$ & $<0.001$ & $<0.001$ & $17.5(0.9)$ & $22.0(2.8)$ & $26.4(2.8)$ & $<0.001$ & $<0.001$ \\
\hline Waist circumference $(\mathrm{cm})$ & $68.1(7.4)$ & $79.0(11.1)$ & $93.5(10.3)$ & $<0.001$ & $<0.001$ & $67.7(7.8)$ & $79.9(9.4)$ & $91.2(9.9)$ & $<0.001$ & $<0.001$ \\
\hline RA duration (years) & $15.1(18.0)$ & $10.2(14.0)$ & $10.1(15.4)$ & 0.637 & 0.628 & - & - & - & - & - \\
\hline mHAQ score & $0.4(0.9)$ & $0.1(0.8)$ & $0.3(1.0)$ & 0.035 & 0.681 & - & - & - & - & - \\
\hline DAS28-ESR & $3.8(1.5)$ & $3.3(1.9)$ & $3.7(1.9)$ & 0.087 & 0.866 & - & - & - & - & - \\
\hline Smoking (\%) & $4(19)$ & $30(27)$ & $2(5)$ & 0.008 & - & $1(4)$ & $9(8)$ & $1(4)$ & 0.672 & - \\
\hline Alcohol drinking (\%) & $12(57)$ & $47(42)$ & $17(45)$ & 0.440 & - & $11(48)$ & $58(49)$ & $11(39)$ & 0.664 & - \\
\hline Exercise habits (\%) & $3(14)$ & $19(17)$ & $9(24)$ & 0.588 & - & $11(48)$ & $67(56)$ & $14(50)$ & 0.675 & - \\
\hline Exercise restriction (\%) & $5(24)$ & $34(30)$ & $9(24)$ & 0.657 & - & $0(0)$ & $2(2)$ & $3(11)$ & 0.026 & - \\
\hline Walking time (min/day) & $60(90)$ & $30(40)$ & $40(70)$ & 0.130 & 0.520 & $60(60)$ & $60(60)$ & $60(60)$ & 0.424 & 0.227 \\
\hline Diabetes (\%) & $0(0)$ & $5(4)$ & $5(13)$ & 0.068 & - & $0(0)$ & $5(4)$ & $1(4)$ & 0.607 & - \\
\hline $\begin{array}{l}\text { DM therapy: insulin } \\
\text { injection (\%) }\end{array}$ & $0(0)$ & $1(20)$ & $0(0)$ & 1.000 & - & $0(0)$ & $4(100)$ & $1(100)$ & - & - \\
\hline $\begin{array}{l}\text { DM therapy: oral } \\
\text { medication (\%) }\end{array}$ & $0(0)$ & $2(40)$ & $4(100)$ & 0.167 & - & $0(0)$ & $2(50)$ & $0(0)$ & 1.000 & - \\
\hline Dyslipidemia (\%) & $6(29)$ & $34(30)$ & $12(32)$ & 0.971 & - & $10(44)$ & $71(60)$ & $15(54)$ & 0.338 & - \\
\hline Medication for DL (\%) & $2(33)$ & $14(41)$ & $7(58)$ & 0.500 & - & $1(10)$ & $20(28)$ & $5(33)$ & 0.403 & - \\
\hline Hypertension (\%) & $6(29)$ & $27(24)$ & $17(45)$ & 0.054 & - & $1(4)$ & $22(19)$ & $12(43)$ & 0.002 & - \\
\hline Medication for HT (\%) & $5(83)$ & $25(93)$ & $15(88)$ & 0.757 & - & $0(0)$ & $17(77)$ & $6(50)$ & 0.103 & - \\
\hline DMARD user (\%) & $20(95)$ & $103(92)$ & $35(92)$ & 0.871 & - & - & - & - & - & - \\
\hline Glucocorticoid user (\%) & $5(24)$ & $26(23)$ & $13(34)$ & 0.398 & - & - & - & - & - & - \\
\hline $\begin{array}{c}\text { Biological DMARD user } \\
(\%)\end{array}$ & $15(71)$ & $66(58.9)$ & $18(47)$ & 0.187 & - & - & - & - & - & - \\
\hline
\end{tabular}

Data are shown as median (interquartile range) or number (\%). Kruskal-Wallis test and chi-square test were used for statistical analysis. Jonckheere-Terpstra test was used for assessment of trend. BMI, body mass index; RA, rheumatoid arthritis; UW, underweight $\left(\mathrm{BMI}<18.5 \mathrm{~kg} / \mathrm{m}^{2}\right)$; NW, normal weight $\left(\geq 18.5 \mathrm{~kg} / \mathrm{m}^{2}\right.$ and $<25$ $\mathrm{kg} / \mathrm{m}^{2}$ ); OW, overweight (BMI $\geq 25 \mathrm{~kg} / \mathrm{m}^{2}$ ); $\mathrm{mHAQ}$, modified Health Assessment Questionnaire; DAS28-ESR, Disease Activity Score 28 based on erythrocyte sedimentation ratio; DM, diabetes mellitus; DL, dyslipidemia; HT, hypertension; DMARD, disease-modifying anti-rheumatic drug.

three groups of patients with RA. In the control group, there was a significant difference between BMI groups in terms of exercise restriction, but there were no significant differences in exercise habits and walking time per day; other characteristics showed a similar trend to patients with RA. In the RA group, DAS28-ESR and $\mathrm{mHAQ}$ scores in the normal weight group were lower than scores in the underweight and overweight groups. We applied a quadratic curve to the scattergrams between BMI and both DAS28-ESR and $\mathrm{mHAQ}$ scores; these two parameters showed the lowest scores near a BMI of $22 \mathrm{~kg} / \mathrm{m}^{2}$ (Figure 1). We also assessed the relationship between $\mathrm{BMI}$ and both DAS28-ESR and mHAQ scores after adjusting for age. BMI didn't show the significant correlation between DAS28-ESR $(r=0.024)$ or mHAQ scores $(r=0.039)$ in whole RA group. In patients who had BMl $<22 \mathrm{~kg} / \mathrm{m}^{2}$ $(\mathrm{n}=88)$, BMI showed no correlation with DAS28-ESR score $(r=-0.06)$. However, there was a negative correlation between BMI and mHAQ score $(r=-0.20)$ in these patients, and the $\mathrm{mHAQ}$ score showed a positive correlation with DAS28-ESR score $(r=0.40)$. In patients who had $B M I>22 \mathrm{~kg} / \mathrm{m}^{2}(\mathrm{n}=83)$, BMl showed no correlation between DAS28-ESR $(r=0.15)$ or mHAQ scores $(r=-0.12)$. However, in the overweight group, BMI showed a positive correlation with DAS28ESR score $(r=0.27)$, but not with mHAQ score $(r=$ $0.01)$. There was a positive correlation between DAS28-ESR and mHAQ scores in the overweight group $(r=0.24)$ (data not shown).

\section{Energy and Nutrient Intake Based on BMI Category}

Energy and nutrient intake status as crude values and intake per ideal body weight (IBW) are shown in Table 2. In the RA group, energy $(p=0.041)$, protein ( $p$ $=0.003)$, and carbohydrate intake $(p=0.015)$ showed 
a

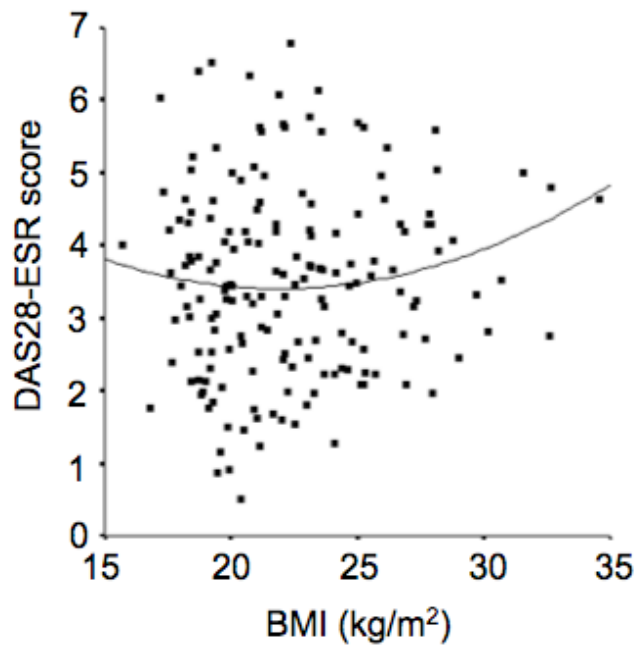

b

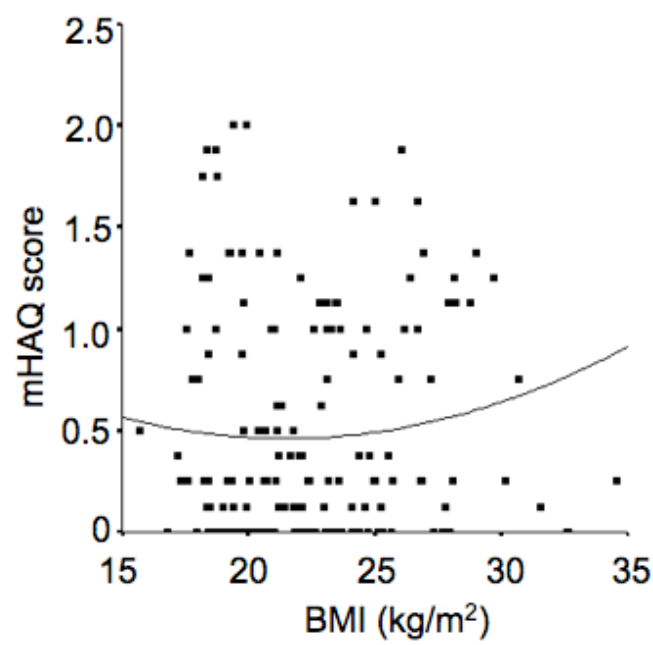

Figure 1: Scattergrams of BMI and RA variables. (a) BMI and DAS28-ESR; (b) BMI and mHAQ score. BMI, body mass index; DAS28-ESR, Disease Activity Score for 28 joints based on erythrocyte sedimentation rate; $m H A Q$, modified Health Assessment Questionnaire.

Table 2: Subject Energy and Nutrient Intake by BMI Group

\begin{tabular}{|c|c|c|c|c|c|c|c|c|c|c|}
\hline & \multicolumn{5}{|c|}{$R A(n=170)$} & \multicolumn{5}{|c|}{ Control $(n=169)$} \\
\hline & $\begin{array}{l}\text { UW } \\
(n=21)\end{array}$ & $\begin{array}{c}N W \\
(n=111)\end{array}$ & $\begin{array}{c}\text { OW } \\
(n=38)\end{array}$ & $\begin{array}{c}p \\
\text { value }\end{array}$ & $\begin{array}{l}p \text { for } \\
\text { trend }\end{array}$ & $\begin{array}{c}\text { UW } \\
(n=23)\end{array}$ & $\begin{array}{c}N W \\
(n=119)\end{array}$ & $\begin{array}{l}\text { OW } \\
(n=27)\end{array}$ & $p$ value & $\begin{array}{l}p \text { for } \\
\text { trend }\end{array}$ \\
\hline Energy (kcal) & $1460(483)$ & $1422(615)$ & $1622(648)$ & 0.041 & 0.036 & $1539(778)$ & $1541(554)$ & $1765(581)$ & 0.417 & 0.492 \\
\hline $\begin{array}{l}\text { Energy intake per IBW (kcal / } \\
\mathrm{kg} \text { ) }\end{array}$ & $27(7)$ & $27(11)$ & $33(13)$ & 0.003 & 0.003 & $29(17)$ & $29(12)$ & $32(12)$ & 0.448 & 0.463 \\
\hline Protein $(\mathrm{g})$ & $53.7(19.5)$ & $51.9(24.2)$ & $64.2(34.0)$ & 0.003 & 0.005 & $56.4(24.0)$ & $64.6(28.9)$ & $63.1(40.3)$ & 0.713 & 0.448 \\
\hline $\begin{array}{l}\text { Protein intake per IBW (g / } \\
\mathrm{kg})\end{array}$ & $1.0(0.3)$ & $1.0(0.6)$ & $1.3(0.6)$ & 0.000 & 0.001 & $1.1(0.6)$ & $1.2(0.6)$ & $1.2(0.8)$ & 0.743 & 0.501 \\
\hline Fat $(\mathrm{g})$ & $44.6(17.4)$ & $38.0(22.0)$ & $46.2(23.3)$ & 0.067 & 0.297 & $42.1(27.1)$ & $47.2(17.8)$ & $51.8(26.6)$ & 0.230 & 0.085 \\
\hline Fat intake per IBW $(\mathrm{g} / \mathrm{kg})$ & $1.2(0.4)$ & $1.4(0.8)$ & $1.1(0.6)$ & 0.022 & 0.078 & $1.3(0.9)$ & $1.1(0.5)$ & $1.0(0.6)$ & 0.223 & 0.081 \\
\hline Carbohydrate (g) & $189.0(76.8)$ & $200.0(78.6)$ & $229.0(91.0)$ & 0.015 & 0.006 & 233.8 (113.5) & $208.0(80.9)$ & $222.2(76.0)$ & 0.067 & 0.888 \\
\hline $\begin{array}{l}\text { Carbohydrate intake per IBW } \\
\qquad(\mathrm{g} / \mathrm{kg})\end{array}$ & $3.6(1.3)$ & $3.8(1.7)$ & $4.6(1.8)$ & 0.001 & $<0.001$ & $4.1(1.9)$ & $3.9(1.8)$ & $4.4(1.6)$ & 0.054 & 0.939 \\
\hline
\end{tabular}

Data are shown as median (interquartile range). Kruskal-Wallis test was used for statistical analysis. Jonckheere-Terpstra test was used for assessment of trend. Energy and nutrient intake are shown as crude value and per ideal body weight (IBW). IBW was calculated as height $\left(\mathrm{m}^{2}\right) \times 22$. BMI, body mass index; RA, rheumatoid arthritis; UW, underweight $\left(\mathrm{BMl}<18.5 \mathrm{~kg} / \mathrm{m}^{2}\right)$; NW, normal weight $\left(\geq 18.5 \mathrm{~kg} / \mathrm{m}^{2}\right.$ and $\left.<25 \mathrm{~kg} / \mathrm{m}^{2}\right)$; OW, overweight $\left(\mathrm{BMI} \geq 25 \mathrm{~kg} / \mathrm{m}^{2}\right)$.

significant differences among the three BMI groups. Energy and nutrient intake per IBW also showed a significant difference among the three BMI groups and showed a positive trend with BMI. The overweight group showed a higher value for energy and nutrient intake compared with the normal and underweight groups. In the control group, carbohydrate intake per IBW in the overweight group was higher than in the normal weight and underweight groups.

\section{Blood Chemistry and Physiological Data Based on BMI Category}

Table 3 shows blood chemistry and physiological data by BMl category. In the RA group, SBP ( $p=$
$0.001)$, DBP $(p=0.011), \operatorname{CRP}(p=0.014)$, UA $(p=$ $0.004)$, TG $(p=0.005)$, FPG $(p<0.001)$, IRI $(p<$ $0.001), \operatorname{HbA} 1 \mathrm{c}(p=0.036)$, leptin $(p<0.001)$, and adiponectin ( $p=0.007)$ showed significant differences among groups, and these parameters, excluding adiponectin, had a tendency to increase with BMI ( $p<$ 0.05 for trend). The control group showed similar trends.

\section{DISCUSSION}

In this study, we assessed and compared subject characteristics, disease activity, ADL, energy and nutrient intake, and some CVD risk-related clinical data 
Table 3: Subject Clinical Data by BMI Group

\begin{tabular}{|c|c|c|c|c|c|c|c|c|c|c|}
\hline & \multicolumn{5}{|c|}{ RA $(n=171)$} & \multicolumn{5}{|c|}{ Control $(n=170)$} \\
\hline & $\begin{array}{c}\text { UW } \\
(n=21)\end{array}$ & $\begin{array}{c}N W \\
(n=112)\end{array}$ & $\begin{array}{c}\text { OW } \\
(n=38)\end{array}$ & $p$ value & $\begin{array}{l}p \text { for } \\
\text { trend }\end{array}$ & $\begin{array}{c}\text { UW } \\
(n=23)\end{array}$ & $\begin{array}{c}N W \\
(n=119)\end{array}$ & $\begin{array}{c}\text { OW } \\
(n=28)\end{array}$ & $p$ value & $\begin{array}{l}p \text { for } \\
\text { trend }\end{array}$ \\
\hline $\mathrm{SBP}(\mathrm{mmHg})$ & $117(36)$ & $130(27)$ & $145(29)$ & 0.001 & $<0.001$ & $109(16)$ & $119(27)$ & $141(26)$ & $<0.001$ & $<0.001$ \\
\hline $\mathrm{DBP}(\mathrm{mmHg})$ & $74(16)$ & $77(14)$ & $82(19)$ & 0.011 & 0.002 & $68(9)$ & $73(16)$ & $84(12)$ & $<0.001$ & $<0.001$ \\
\hline $\operatorname{ESR}(\mathrm{mm} / \mathrm{hr})$ & $20(25)$ & $20(23)$ & $30(36)$ & 0.052 & 0.075 & $8(8)$ & $10(9)$ & $8(12)$ & 0.267 & 0.45 \\
\hline CRP (mg / dl) & $0.10(0.22)$ & $0.10(0.34)$ & $0.32(0.91)$ & 0.014 & 0.007 & $0.01(0.01)$ & $0.02(0.04)$ & $0.04(0.11)$ & 0.001 & $<0.001$ \\
\hline $\mathrm{UA}(\mathrm{mg} / \mathrm{dl})$ & $4.1(1.1)$ & $4.3(1.6)$ & $5.1(1.3)$ & 0.004 & 0.001 & $4.3(1.0)$ & $4.6(1.0)$ & $4.7(2.0)$ & 0.034 & 0.01 \\
\hline T-chol (mg / dl) & $196(44)$ & $212(44)$ & $206(60)$ & 0.533 & 0.407 & $214(56)$ & $219(45)$ & $209(32)$ & 0.546 & 0.37 \\
\hline TG (mg / dl) & $61(30)$ & $79(49)$ & $88(57)$ & 0.005 & 0.006 & $52(35)$ & $72(48)$ & $88(43)$ & $<0.001$ & $<0.001$ \\
\hline HDL-chol (mg / dl) & $72(12)$ & $69(25)$ & $64(18)$ & 0.056 & 0.018 & $85(42)$ & $70(23)$ & $62(15)$ & $<0.001$ & $<0.001$ \\
\hline LDL-chol (mg / dl) & $112(31)$ & $120(38)$ & $119(55)$ & 0.169 & 0.104 & $109(46)$ & $124(40)$ & $113(35)$ & 0.403 & 0.461 \\
\hline $\mathrm{FPG}(\mathrm{mg} / \mathrm{dl})$ & $79(8)$ & $82(10)$ & $87(13)$ & 0.000 & $<0.001$ & $83(12)$ & $89(10)$ & $93(12)$ & 0.002 & $<0.001$ \\
\hline IRI ( $\mu \mathrm{IU} / \mathrm{ml})$ & $3.5(2.2)$ & $4.0(2.9)$ & $6.2(3.6)$ & 0.000 & $<0.001$ & $2.0(0.9)$ & $3.1(1.6)$ & $4.9(2.6)$ & $<0.001$ & $<0.001$ \\
\hline $\begin{array}{c}\text { HbA1c (NGSP value) } \\
(\%)\end{array}$ & $5.3(0.4)$ & $5.5(0.5)$ & $5.6(0.7)$ & 0.036 & 0.011 & $5.6(0.2)$ & $5.7(0.4)$ & $5.6(0.5)$ & 0.182 & 0.563 \\
\hline Leptin (ng / ml) & $2.2(4.4)$ & $6.5(6.3)$ & $17.1(11.0)$ & 0.000 & $<0.001$ & $1.9(1.8)$ & $5.6(4.9)$ & $12.7(10.8)$ & $<0.001$ & $<0.001$ \\
\hline Adiponectin $(\mu \mathrm{g} / \mathrm{ml})$ & $19.7(11.0)$ & $16.1(12.9)$ & $12.5(10.0)$ & 0.007 & 0.003 & $12.9(17.1)$ & $12.0(8.6)$ & $10.1(5.7)$ & $<0.001$ & 0.008 \\
\hline
\end{tabular}

Data are shown as median (interquartile range). Kruskal-Wallis test was used for statistical analysis. Jonckheere-Terpstra test was used for assessment of trend. $\mathrm{BMI}$, body mass index; RA, rheumatoid arthritis; UW, underweight $\left(\mathrm{BMI}<18.5 \mathrm{~kg} / \mathrm{m}^{2}\right)$; NW, normal weight $\left(\geq 18.5 \mathrm{~kg} / \mathrm{m}^{2}\right.$ and $\left.<25 \mathrm{~kg} / \mathrm{m}^{2}\right)$; OW, overweight $(\mathrm{BMI} \geq 25$ $\mathrm{kg} / \mathrm{m}^{2}$ ); SBP, systolic blood pressure; DBP, diastolic blood pressure; ESR, erythrocyte sedimentation rate; CRP, C reactive protein; UA, uric acid; T-chol, total cholesterol; TG, triglyceride; HDL-chol, high-density lipoprotein cholesterol; LDL-chol, low-density lipoprotein cholesterol; FPG, fasting plasma glucose; IRI, immuno reactive insulin; NGSP, National Glycohemoglobin Standardization Program.

based on BMI category in female patients with and without RA. In patients with RA, patient age showed a positive correlation with BMI. One report in Japan showed that obesity in older females was higher than that in younger females [19], and our results in RA patients are consistent with this report. $A D L$ and disease activity scores in the normal weight group were better than scores in the underweight and overweight groups, and these parameters were best at a BMI of 22 $\mathrm{kg} / \mathrm{m}^{2}$. The reason the underweight group showed higher disease activity might be related to a report that suggested that high disease activity is caused by acute inflammation related to decreased skeletal muscle mass [9]. The reason for lower ADL in the underweight group may also be related to high disease activity that has been shown in underweight patients with RA [10]. Our results are consistent with these reports. Disease activity scores were higher and ADL was lower in the overweight group than in the normal weight group. In patients with RA, obesity is related to attenuation of medication effects, although the reason for this is unclear [8]. Obesity is also related to high disease activity in patients with RA [7], and high disease activity is related to low ADL in patients with RA [20]. Based on these reports and our results, it is possible that patients with RA who are underweight or overweight may have higher disease activity or lower ADL than normal weight patients, and maintaining a normal weight might be a healthy status indicator in patients with RA. However, the benefit of weight control on disease activity and $A D L$ in underweight or overweight patients with RA should be assessed.

In terms of energy and nutrient intake in patients with RA, energy, protein, and carbohydrate intake in the overweight group were higher than values in the normal weight and underweight groups. However, the status of energy and protein intake per IBW was similar in the underweight and normal weight groups. Carbohydrate intake per IBW showed a strong positive correlation with $\mathrm{BMI}$ in patients with $\mathrm{RA}$, and the overweight control group also showed a higher carbohydrate intake per IBW than the underweight and normal weight control groups. In terms of weight loss in obese subjects, it is reported that the kind of energy source nutrient affects weight loss, and restriction from carbohydrate-derived energy is most effective for weight loss [21]. The current study also suggests that the kind of energy-derived nutrient affects weight in daily life, as our results showed a positive correlation between $\mathrm{BMI}$ and carbohydrate intake in patients with RA. Carbohydrate intake restriction in overweight patients with RA may contribute to weight loss, and an increase in carbohydrate intake in underweight patients 
with RA may help with weight gain to help patients maintain a normal weight.

In patients with $\mathrm{RA}$, higher $\mathrm{BMI}$ was related to higher blood pressure, CRP, TG, FPG, IRI, leptin, and lower adiponectin. This trend was similar in our control population, and has been reported in a general population [2]. Our results suggest that weight control in overweight patients with RA may improve CVDrelated clinical data. It is reported that underweight in patients with RA is related to CVD risk [11], although our data showed that underweight patients with RA had the most healthy CVD-related clinical data among the three BMI categories. CVD risk in patients with RA is not fully explained with only traditional CVD risk factors, such as hypertension, glucose intolerance, and dyslipidemia; inflammation and disease activity also affect CVD risk [6]. These facts and our results may suggest that normal weight patients with RA whose inflammation status, disease activity, and CVD-related clinical data were relatively good compared with underweight and overweight groups may represent a lower CVD risk group among RA patients.

This study has some limitations. First, this subanalysis is cross-sectional. Longitudinal and intervention studies are needed to clarify the etiology between BMI and disease activity, ADL, and CVDrelated clinical data. Second, we analyzed only women because the study population was limited. Data are also needed for male patients with RA. Third, in this study, although there was no significant difference in medication status for RA among three BMI category groups, some reports showed medications for RA treatment affected lipid metabolism profiles [22-24]. Fourth, we assessed Japanese population's data. Because of Asian ethnic characteristics, Japanese population with lower BMI might be susceptible to the change of obesity-related metabolism compared to other ethnics. The differences in baseline characteristic of BMI might affect the results in different studies [25, 26]. In this aspect, careful interpretation of the results regarding the effects of BMI in different ethnic population should be required.

\section{CONCLUSIONS}

In patients with RA, maintaining a normal weight may help keep disease activity, ADL, and CVD-related clinical data at relatively good levels. Energy intake, especially carbohydrates, may contribute to increased $\mathrm{BMI}$ in patients with RA.

\section{ACKNOWLEDGEMENT}

Osaka City University Hospital Center for Drug \& Food Clinical Evaluation managed the data from the TOMORROW study.

\section{DISCLOSURE OF INTERESTS}

Research grants and/or lecture fees have been provided to Tatsuya Koike from AbbVie, Astellas Pharma Inc., Bristol-Myers Squibb, Chugai Pharmaceutical, Eisai, Janssen, Lilly, Mitsubishi Tanabe Pharma Corporation, MSD, Ono Pharmaceutical, Pfizer, Roche, Takeda Pharmaceutical, Teijin Pharma, and UCB. All other authors have no conflicts of interest to disclose.

\section{STATEMENT OF AUTHORSHIP}

YM analyzed the data and drafted the manuscript. YS, MT, TO, KM, and KI participated in the study design and collected data. $\mathrm{DH}$ contributed to data analysis, statistical analysis, and interpretation of results. TK carried out the study design and data collection, and supervised drafting the manuscript.

\section{FOUNDATION}

There was no specific foundation for this study.

\section{REFERENCES}

[1] $\mathrm{Ng} \mathrm{M}$, Fleming $\mathrm{T}$, Robinson M, Thomson B, Graetz N, Margono $\mathrm{C}$, et al. Global, regional, and national prevalence of overweight and obesity in children and adults during 19802013: a systematic analysis for the Global Burden of Disease Study 2013. Lancet 2014; 384(9945): 766-81. http://dx.doi.org/10.1016/S0140-6736(14)60460-8

[2] Boden G. Obesity, insulin resistance and free fatty acids. Curr Opin Endocrinol Diabetes Obes 2011; 18(2): 139-43. http://dx.doi.org/10.1097/MED.0b013e3283444b09

[3] Hubert HB, Feinleib M, McNamara PM, Castelli WP. Obesity as an independent risk factor for cardiovascular disease: a 26-year follow-up of participants in the Framingham Heart Study. Circulation 1983; 67(5): 968-77.

http://dx.doi.org/10.1161/01.CIR.67.5.968

[4] Scott DL, Wolfe F, Huizinga TW. Rheumatoid arthritis. Lancet 2010; 376(9746): 1094-108.

http://dx.doi.org/10.1016/S0140-6736(10)60826-4

[5] Maradit-Kremers H, Crowson CS, Nicola PJ, Ballman KV, Roger VL, Jacobsen SJ, et al. Increased unrecognized coronary heart disease and sudden deaths in rheumatoid arthritis: a population-based cohort study. Arthritis Rheum 2005; 52(2): 402-11.

http://dx.doi.org/10.1002/art.20853

[6] Amaya-Amaya J, Sarmiento-Monroy JC, Mantilla RD, Pineda-Tamayo R, Rojas-Villarraga A, Anaya JM. Novel risk factors for cardiovascular disease in rheumatoid arthritis. Immunol Res 2013; 56(2-3): 267-86.

http://dx.doi.org/10.1007/s12026-013-8398-7 
[7] Ajeganova S, Andersson ML, Hafström I; BARFOT Study Group. Association of obesity with worse disease severity in rheumatoid arthritis as well as with comorbidities: a long-term followup from disease onset. Arthritis Care Res (Hoboken) 2013; 65(1): 78-87. http://dx.doi.org/10.1002/acr.21710

[8] Sandberg ME, Bengtsson C, Källberg H, Wesley A, Klareskog L, Alfredsson L, et al. Overweight decreases the chance of achieving good response and low disease activity in early rheumatoid arthritis. Ann Rheum Dis 2014. http://dx.doi.org/10.1136/annrheumdis-2013-205094

[9] Munro R, Capell H. Prevalence of low body mass in rheumatoid arthritis: association with the acute phase response. Ann Rheum Dis 1997; 56(5): 326-9. http://dx.doi.org/10.1136/ard.56.5.326

[10] Fukuda W, Omoto A, Ohta T, Majima S, Kimura T, Tanaka T, et al. Low body mass index is associated with impaired quality of life in patients with rheumatoid arthritis. Int $\mathrm{J}$ Rheum Dis 2013; 16(3): 297-302. http://dx.doi.org/10.1111/1756-185X.12079

[11] Kremers HM, Nicola PJ, Crowson CS, Ballman KV, Gabriel SE. Prognostic importance of low body mass index in relation to cardiovascular mortality in rheumatoid arthritis. Arthritis Rheum 2004; 50(11): 3450-7. http://dx.doi.org/10.1002/art.20612

[12] Matsumoto $Y$, Sugioka $Y$, Tada $M$, Okano T, Mamoto T, Inui $\mathrm{K}$, et al. Relationships between serum 25-hydroxycalciferol, vitamin $\mathrm{D}$ intake and disease activity in patients with rheumatoid arthritis - TOMORROW study. Mod Rheumatol 2014 Sep 11: 1-5. [Epub ahead of print] http://dx.doi.org/10.3109/14397595.2014.952487

[13] Arnett FC, Edworthy SM, Bloch DA, McShane DJ, Fries JF, Cooper NS, et al. The American Rheumatism Association 1987 revised criteria for the classification of rheumatoid arthritis. Arthritis Rheum 1988; 31(3): 315-24. http://dx.doi.org/10.1002/art.1780310302

[14] Charlton K, Kowal P, Soriano MM, Williams S, Banks E, Vo $\mathrm{K}$, et al. Fruit and vegetable intake and body mass index in a large sample of middle-aged Australian men and women. Nutrients 2014; 6(6): 2305-19. http://dx.doi.org/10.3390/nu6062305

[15] Matsuzawa Y, Tokunaga K, Kotani K, Keno Y, Kobayashi T, Tarui S. Simple estimation of ideal body weight from body mass index with the lowest morbidity. Diabetes Res Clin Pract 1990; 10(Suppl 1): S159-64. http://dx.doi.org/10.1016/0168-8227(90)90157-O

[16] van der Heijde DM, van 't Hof MA, van Riel PL, Theunisse LA, Lubberts EW, van Leeuwen MA, et al. Judging disease activity in clinical practice in rheumatoid arthritis: first step in the development of a disease activity score. Ann Rheum Dis 1990; 49(11): 916-20.

http://dx.doi.org/10.1136/ard.49.11.916
[17] Pincus T, Summey JA, Soraci SA Jr, Wallston KA, Hummon NP. Assessment of patient satisfaction in activities of daily living using a modified Stanford Health Assessment Questionnaire. Arthritis Rheum 1983; 26(11): 1346-53.

http://dx.doi.org/10.1002/art.1780261107

[18] Kobayashi S, Murakami K, Sasaki S, Okubo H, Hirota N, Notsu $A$ et al. Comparison of relative validity of food group intakes estimated by comprehensive and brief-type selfadministered diet history questionnaires against $16 \mathrm{~d}$ dietary records in Japanese adults. Public Health Nutr 2011; 14(7): 1200-11. http://dx.doi.org/10.1017/S1368980011000504

[19] National Health and Nutrition Survey, Health Service Bureau, Ministry of Health, Labor, and Welfare, Japan, 2012.

[20] García-Poma A, Segami MI, Mora CS, Ugarte MF, Terrazas $\mathrm{HN}$, Rhor EA, et al. Obesity is independently associated with impaired quality of life in patients with rheumatoid arthritis. Clin Rheumatol 2007; 26(11): 1831-5.

\section{http://dx.doi.org/10.1007/s10067-007-0583-4}

[21] Gardner CD, Kiazand A, Alhassan S, Kim S, Stafford RS, Balise RR, et al. Comparison of the Atkins, Zone, Ornish, and LEARN diets for change in weight and related risk factors among overweight premenopausal women: the A TO Z Weight Loss Study: a randomized trial. JAMA 2007; 297(9): 969-77.

http://dx.doi.org/10.1001/jama.297.9.969

[22] Kerekes G Nurmohamed MT, González-Gay MA, Seres I, Paragh G, Kardos Z, et al. Rheumatoid arthritis and metabolic syndrome. Nat Rev Rheumatol 2014; 10(11): 69196 http://dx.doi.org/10.1038/nrrheum.2014.121

[23] Kiortsis DN, Mavridis AK, Filippatos TD, Vasakos S, Nikas SN, Drosos AA. Effects of infliximab treatment on lipoprotein profile in patients with rheumatoid arthritis and ankylosing spondylitis. J Rheumatol 2006; 33(5): 921-3.

[24] Derdemezis CS, Filippatos TD, Voulgari PV, Tselepis AD, Drosos AA, Kiortsis DN. Effects of a 6-month infliximab treatment on plasma levels of leptin and adiponectin in patients with rheumatoid arthritis. Fundam Clin Pharmacol 2009; 23(5): 595-600. http://dx.doi.org/10.1111/j.1472-8206.2009.00717.x

[25] Mirpourian $M$, Salesi $M$, Abdolahi $H$, Farajzadegan $Z$, Karimzadeh $\mathrm{H}$. The association of body mass index with disease activity and clinical response to combination therapy in patients with rheumatoid arthritis. J Res Med Sci 2014; 19(6): 509-14.

[26] Zarpellon RS, Dias MM, Skare TL. Nutritional profile in rheumatoid arthritis. Rev Bras Reumatol 2014; 54(1): 68-72. http://dx.doi.org/10.1016/j.rbr.2014.01.007

Received on 14-11-2014

Accepted on 16-12-2014

Published on 22-12-2014

DOI: http://dx.doi.org/10.6000/1929-5634.2014.03.04.4

(C) 2014 Matsumoto et al.; Licensee Lifescience Global.

This is an open access article licensed under the terms of the Creative Commons Attribution Non-Commercial License (http://creativecommons.org/licenses/by-nc/3.0/) which permits unrestricted, non-commercial use, distribution and reproduction in any medium, provided the work is properly cited. 